\title{
DIREITOS FUNDAMENTAIS A PRESTAÇÕES SOCIAIS E CRISE: ALGUMAS APROXIMAÇÕES

\author{
FUNDAMENTAL RIGHTS TO SOCIAL BENEFITS AND CRISIS: SOME REMARKS
}

Ingo Wolfgang Sarlet*

Resumo: A despeito de existirem muitas diferenças na forma pela qual os países reconhecem, protegem e promovem direitos sociais, a previsão de direitos sociais no direito internacional e a difusão no contexto regional e mesmo em constituições nacionais assegura um certo terreno comum em termos de teoria e prática. Neste artigo, discutimos não apenas diferentes dimensões da crise experimentada pelos direitos fundamentais sociais, mas também o problema da sua implementação. Na sequência, enfocamos a chamada proibição de retrocesso e a proteção do núcleo essencial dos direitos sociais (e mesmo o mínimo existencial), buscando verificar se tais garantias podem operar como um instrumento efetivo, de modo a assegurar pelo menos determinados níveis de proteção social com base constitucional em tempos de crise econômica e social.

Palavras-chave: Direitos sociais. Proibição de retrocesso. Conteúdo essencial. Crise econômica.

\begin{abstract}
Although there are a lot of differences in the way countries recognize, protect and promote social rights, the provision of social rights in international law and the diffusion in regional and even at national constitutional contexts provides certain common ground in terms of theory and practice. In this paper, we discuss not only different dimensions of the crises experimented by fundamental social rights, but also the problem of their adjudication. Then, our focus is the prohibition of retrogression and the protection of the minimum core of social rights (or even the existential minimum), trying to find out if those guarantees could be an effective instrument to assure at least certain levels of social protection on constitutional basis in times of social and economic crisis.
\end{abstract}

Keywords: Social Rights. Prohibition of retrogression. Minimum core. Economic crisis.

\footnotetext{
* Doutor em Direito pela Ludwig Maximillians Universität München; Coordenador do Programa de Pós-Graduação em Direito - Mestrado e Doutorado; Professor Titular da Faculdade de Direito e dos Programas de Mestrado e Doutorado em Direito e em Ciências Criminais da Pontifícia Universidade Católica do Rio Grande do Sul, Avenida Ipiranga, 6681 - Partenon, Porto Alegre - RS, 90619-900, Coordenador do Grupo de Estudos e Pesquisas em Direitos Fundamentais (CNPq); iwsarlet@gmail.com
} 


\section{Considerações Iniciais}

Os chamados direitos sociais, econômicos e culturais (doravante referidos apenas como direitos sociais), com os direitos civis e políticos ${ }^{1}$, ao menos em se considerando o direito internacional dos direitos humanos e o número de Estados que ratificaram os dois mais abrangentes pactos na matéria, pertencem - de acordo com esse critério - ao que se poderia designar um patrimônio jurídico comum da humanidade, pois, mesmo no plano supranacional, o arcabouço de textos jurídicosque reconhece e protege direitos sociais foi objeto de significativa ampliação. Para tanto, além do Pacto de Direitos Sociais da ONU já referido, basta lançar um olhar para as convenções da Organização Internacional do Trabalho (OIT) e os diversos tratados em nível regional, como é o caso, em caráter ilustrativo, do Protocolo de São Salvador, que acrescentou os direitos sociais ao Sistema Interamericano, bem como, no plano europeu, a Carta Social Europeia e, mais recentemente, a previsão de alguns direitos sociais na Carta dos Direitos Fundamentais da União Europeia (2000), dotada de caráter vinculante com a entrada em vigor do Tratado de Lisboa (2009).

Mas por mais importante que seja a perspectiva supranacional, é na esfera do direito interno, com destaque para o direito constitucional, que melhor se pode aferir o quanto e em que medida os direitos sociais - ainda mais quando em causa a sua condição de direitos fundamentais - correspondem a uma gramática universal e comum à maioria dos países. O que se percebe, nesse contexto, é que seguem existindo diversos modelos, que vão da total ausência de direitos sociais a modelos que poderiam ser chamados de fortes - ao menos sob certo ponto de vista - em matéria do reconhecimento e proteção de tais direitos.

Um primeiro grupo de países pode ser identificado com os Estados Unidos da América e a Inglaterra, com a ressalva que no segundo caso não se trata de um sistema constitucional que tenha adotado uma constituição escrita, em sentido formal. Em ambos os casos, mas especialmente nos Estados Unidos, que possuem uma constituição escrita, a constitucionalização de normas de justiça social (mesmo na condição de normas definidoras de fins estatais) e de direitos sociais não logrou sucesso nem na esfera político-legislativa nem por meio da jurisprudência da Suprema Corte Norte-Americana, apesar de algumas importantes vozes e tentativas nesse sentido recorde-se, aqui, a tentativa de Franklin D. Roosevelt (1944) de fazer aprovar uma segunda declaração de direitos, no caso, dedicada aos direitos sociais. ${ }^{2}$ Tanto nos Estados Unidos quanto na Inglaterra e em outros Estados que trilharam caminho similar, a proteção social segue ocorrendo por meio da legislação ordinária e políticas públicas, de tal sorte que a ausência de direitos sociais no texto constitucional não implica a ausência de determinados níveis de justiça social e mesmo de um Estado Social. Todavia,

\footnotetext{
1 Aqui utilizamos a terminologia adotada pelos dois Pactos Internacionais de 1966.

2 Sobre o tópico, ver, por todos, Sunstein (2004).
} 
a despeito disso, é possível afirmar que a inserção de normas nas constituições que disponham sobre tarefas a serem cumpridas pelo Estado em matéria de justiça social ou mesmo consagrando direitos sociais, parece constituir a regra geral, muito embora sigam sendo significativas as diferenças registradas.

Assim, ao passo que na Lei Fundamental da Alemanha (1949), além de alguns direitos econômicos e da proteção da maternidade e da família, não foram contemplados direitos sociais, mas apenas uma cláusula geral de justiça social, de acordo com a qual a Alemanha é um Estado Social e Democrático de Direito, cláusula que reclama a concretização legislativa, em outros casos, como atende o exemplo da Espanha, pode-se falar de um modelo híbrido, visto que alguns direitos sociais foram consagrados como direitos fundamentais (v.g., a liberdade sindical e o direito à educação), tendo o constituinte igualmente previsto uma cláusula geral para o Estado Social. Todavia, além de tal cláusula geral, o constituinte espanhol contemplou, no título dos princípios da ordem social, uma série de normas definidoras de fins e tarefas estatais, que, todavia, não ostentam a condição de autênticos direitos fundamentais, sequer podendo ser exigidas como direitos subjetivos por meio do assim chamado recurso de amparo, que fornece acesso ao Tribunal Constitucional, o que não significa que tais normas sejam completamente destituídas de normatividade, já que seguem sendo parâmetro do controle de constitucionalidade. Já no caso de países como a África do Sul, o Brasil, a Colômbia e Portugal, os direitos sociais foram positivados como direitos fundamentais, mas, ainda, assim, existem diferenças consideráveis a serem consideradas, especialmente quando se trata do regime jurídico-constitucional atribuído a tais direitos. Assim, se no caso de Portugal os direitos sociais, econômicos e culturais e os direitos, liberdades e garantias (que correspondem, grosso modo, aos direitos civis e políticos e aos direitos e liberdades dos trabalhadores), a Constituição da República Portuguesa (1976) limitou a aplicabilidade imediata das normas de direitos fundamentais aos direitos, liberdades e garantias e direitos análogos, além de não - ao menos não expressamente - incluir os direitos sociais no elenco dos limites materiais à revisão constitucional, ${ }^{3}$ no Brasil, a Constituição Federal de 1988 incluiu um elenco generoso (na ocasião, possivelmente, sem precedentes e paralelos no constitucionalismo contemporâneo) de direitos sociais e direitos dos trabalhadores no Título dos Direitos e Garantias Fundamentais, além de um conjunto de princípios e regras versando sobre matéria econômica, social, ambiental e cultural nos títulos da ordem constitucional econômica e social, o que também ocorreu - em linhas gerais - no caso da Constituição da Colômbia (1991). Destaque-se que tanto no Brasil quanto na Colômbia, segundo a doutrina e a jurisprudência constitucional, ainda que não de modo uníssono e respeitada uma série

\footnotetext{
3 Conforme, por todos, Miranda (1993, p. 275 e ss, p. 339), muito embora admitindo que os direitos sociais possam ser considerados limites materiais implícitos à revisão constitucional (MIRANDA, 1993, p. 340-341). Em sentido diverso, contudo, ver Novais (2010), que sustenta a existência de um regime jurídico-constitucional substancialmente unificado dos direitos fundamentais.
} 
de peculiaridades, os direitos sociais a prestações são considerados direitos exigíveis (na condição de direitos subjetivos e mesmo na esfera individual), o que, por sua vez, não corresponde ao modelo sul-africano, no qual, a despeito de uma série de direitos sociais na Constituição e da criação de uma Corte Constitucional, a normatividade dos direitos sociais a prestações (embora reconhecida) é manejada, em geral, de modo distinto em relação aos direitos civis e políticos, ${ }^{4}$ aspectos que serão objeto de maior desenvolvimento mais adiante, pois também dizem respeito às diferentes estratégias de litigância judicial em matéria de direitos sociais.

Por outro lado, a maior eficácia jurídica e efetividade das normas de justiça social e/ou dos direitos fundamentais sociais está, essencialmente, atrelada ao forte influxo do contexto social, econômico e político e aos mecanismos institucionais e procedimentais criados e desenvolvidos para a sua proteção e promoção. Aqui, é possível destacar o papel do Poder Judiciário, de tal sorte que resulta quase evidente, na esteira da proposta de Tushnet (2008), que é possível se falar em direitos fortes e cortes fracas ou mesmo variações sobre o tema, o que também voltará a ser objeto de atenção.

$\mathrm{O}$ que se percebe é que tanto o conceito quanto o conteúdo e o regime jurídico dos direitos sociais, embora quanto ao seu reconhecimento no plano textual, ainda mais do ponto de vista internacional, não obedecem a um padrão uniforme. A afirmação de que os direitos sociais pertencem a uma espécie de patrimônio comum universal deve ser conciliada, portanto, tanto com as diferenças em parte já apontadas quanto com o fato de que os direitos sociais, notadamente na sua dimensão de direitos a prestações, são fortemente impactados pelo grau de desenvolvimento e prosperidade econômica dos Estados individualmente considerados, mas também, e cada vez mais, na perspectiva transnacional, o que remete, entre outros aspectos, ao fenômeno da globalização e das crises econômicas, o que voltará a ser objeto de atenção.

Além disso, em uma época em que se fala tanto de um constitucionalismo de diferentes níveis, ou mesmo de um transconstitucionalismo, ${ }^{5}$ os diversos planos de positivação (das fontes dos direitos sociais enquanto normas jurídicas) e de proteção (nacional, regional e internacional, além da descentralização e diferenças no plano interno de cada Estado) dos direitos sociais colocam desafios à própria coordenação, maior ou menor, entre as diferentes esferas e órgãos que as representam, o que também assume relevância para os níveis de proteção e promoção dos direitos sociais como direitos exigíveis e efetivos.

Nessa perspectiva, se por um lado, o direito internacional dos direitos humanos e a maciça ratificação (ainda que não total) do pacto de direitos sociais, econômicos e culturais exercem a função de um amálgama jurídico-social, pois formalmente vinculantes da expressiva maioria dos Estados da comunidade internacional, por outro lado, tanto o nem sempre frutífero diálogo entre os organismos suprana-

\footnotetext{
4 Sobre os direitos sociais na África do Sul, ver, especialmente, Liebenberg (2010).

5 Sobre o tema, ver, por todos, Neves (2009).
} 
cionais (entre eles, os Tribunais) e os internos, mas acima de tudo o déficit de implementação dos parâmetros internacionais (com destaque para os parâmetros sociais elaborados e monitorados pela ONU e outros atores do sistema), também a falta de efetividade dos objetivos constitucionais e direitos sociais remetem ao crucial e dramaticamente atual problema da força do Direito e dos Direitos em face da crise social e econômica, e colocam em cheque a autoridade e a eficácia do sistema internacional dos direitos humanos em matéria de direitos sociais.

Assim, considerando o enfoque da presente abordagem e antes de adentrarmos ao problema da exigibilidade dos direitos sociais a prestações como direitos fundamentais do ponto de vista jurídico - com amplo destaque para a perspectiva constitucional - seguem algumas notas sobre o contexto de crise pela qual passam (ainda e cada vez mais) o modelo do Estado Social e os direitos fundamentais de um modo geral, crise que guarda relação - mas não no sentido de uma exclusividade com o fenômeno da globalização política e econômica.

\section{Os direitos sociais em tempos de crise: crise de identidade, crise de efetividade e crise de confiança}

O Estado Social (ou o chamado Estado de Bem-Estar Social, de acordo com a conhecida fórmula do Welfare State) - compreendido (para efeitos de um acordo semântico) como um Estado que promove justiça social mediante os procedimentos e limites do Estado Democrático de Direito (portanto, de um Estado Social e Democrático de Direito ${ }^{6}$ ), e, consequentemente, também os direitos sociais, se encontram fortemente impactados pela crise econômica e, em certo sentido, também se encontram vivenciando uma crise. Que a crise não se revela da mesma forma em todos os ambientes e em todos os tempos é algo que não precisaria ser enfatizado, bastando, aqui, uma referência ao atual quadro na Europa, como atendem os exemplos da Grécia, Portugal e Espanha, apenas para mencionar os mais agudos e que têm obtido maior divulgação pelos meios de comunicação. Que o Estado Social se encontra gravemente enfermo, contudo, corresponde a uma constatação que já perdeu há muito o sabor de novidade, sendo reiterada como se fosse um mantra já desde meados da década de 1970, mas, especialmente, a contar da década de 1980. Por outro lado, é preciso reconhecer que as diversas manifestações concretas do Estado Social são bastante distintas entre si, mesmo em se tratando de autênticos Estados Democráticos de Direito, o que pode ser bem ilustrado com o exemplo da positivação, ou não, de direitos sociais, mas, em especial, se avaliando-se o regime jurídico de tais direitos e a sua eficácia social, precisamente a que mais se ressente em tempos de crise. Além disso - mas em boa parte por isso - há mesmo quem coloque a interrogação de

\footnotetext{
6 Conforme o conceito formulado por Zacher (1987). Nota de margem n. 96, conceito que evidentemente assume, aqui, um caráter aproximativo e que recebe sua respectiva formatação de acordo com as peculiaridades de cada ordem jurídico-constitucional que pode ser reconduzida à noção de Estado Social.
} 
um "Adeus ao Estado Social"”, pois a evolução mais recente, em especial, a crise de efetividade dos direitos sociais (sejam eles positivados como direitos fundamentais, sejam direitos atribuídos pela legislação infraconstitucional que concretiza as tarefas do Estado Social) e o gradativo esvaziamento do papel do Estado (pelo menos na condição de Estado prestacional e interventivo) justificam que tal indagação, sobre a sobrevivência do Estado Social, siga atual e relevante.

Mas a crise do Estado Social, como apontou Santos (1998, p. 17-18), é também, e de certa forma a crise da Democracia, que, especialmente em virtude do impacto da globalização econômica e do consenso democrático liberal (amigo de um enfraquecimento do Estado e protagonista de uma concepção minimalista de democracia), tem levado a um gradativo esvaziamento da própria democracia em sentido material, com manifesto prejuízo para os direitos fundamentais em geral e os direitos sociais em particular. Tal enfraquecimento do Estado e da Democracia reflete-se, entre outros aspectos, notadamente quando relacionado à crise econômica, na diminuição da capacidade do Estado em assegurar a fruição dos direitos fundamentais, com destaque, aqui, para os direitos sociais, reforçando, além disso, a dominação do poder econômico em detrimento do poder estatal e da ordem jurídica. ${ }^{8}$ Os níveis alarmantes de desemprego, a crescente exclusão social, a dependência - quando e enquanto o Estado e a sociedade tiverem condições de suportar - de um número cada vez maior de pessoas das políticas de assistência social do Estado ou da caridade, com reflexos inclusive na autoestima do indivíduo, fornecem o caldo para o que Santos (1998, p. 23 e ss) designou de uma espécie de "fascismo societal", no sentido de um "Apartheid Social", que, a depender do lugar, do contexto e da sua dimensão, chega a gerar a divisão da cartografia urbana em zonas civilizadas, que ainda vivem sob o signo do contrato social e mantém os parâmetros e procedimentos do Estado Democrático (e Social) de Direito, e zonas marcadas pela exclusão e pela selvageria, caracterizadas por uma espécie de retorno a um estado da natureza à feição de Hobbes, na qual o próprio Estado, a pretexto de salvaguardar a ordem e os direitos fundamentais, passa a atuar de forma predatória e opressiva, além da subversão gradual da ordem jurídica democrática. No que diz respeito aos direitos sociais a prestações, assume particular relevo a existência - na perspectiva apontada por Santos - de um fascismo financeiro, que, mediante a especulação financeira e o domínio dos mercados, opera em um "espaço-tempo virtualmente global e instantâneo", que, combinado com a lógica de lucro especulativo que o sustenta, confere um imenso poder discricionário ao capital financeiro, praticamente incontrolável, apesar de suficientemente poderoso para abalar a economia real ou a estabilidade política de qualquer país (SANTOS, 1998, p. 24 e ss).

\footnotetext{
7 De acordo com o sugestivo título da obra de Loureiro (2010), Adeus ao Estado Social? A Segurança Social entre o Crocodilo da Economia e a Medusa da Ideologia dos "Direitos Adquiridos."

8 Conforme, por todos, Faria, (1996, p. 127 e ss).
} 
Nesse mesmo contexto, os segmentos excluídos da população, vítimas das mais diversas formas de violência física, simbólica ou moral, resultantes em boa parte (mas não exclusivamente) da opressão socioeconômica, acabam não aparecendo como portadores de direitos subjetivos públicos, ficando excluídos da titularidade de direitos fundamentais, de modo que a diminuição do papel do Estado (especialmente em razão do seu dever de proteção e promoção dos direitos fundamentais) nem sempre significa mais liberdade e mais democracia, podendo, pelo contrário, contribuir para o déficit da efetividade do Direito e dos direitos (FARIA, 1996, p. 145-146). Em uma outra escala - mas vinculada ao processo referido - a globalização e a escala mundial da crise econômica (hoje cada vez mais também uma crise do capitalismo financeiro e da redução do capitalismo produtivo) - contribuem decisivamente para o enfraquecimento da soberania interna e externa dos Estados, o que, entre outros fatores, tem levado a um condicionamento da política (das decisões políticas) pelos equilíbrios macroeconômicos, que limitam (e mesmo condicionam) as intervenções regulatórias do Estado, indicando que a crise do Estado Social é também uma crise integral do Estado e do seu papel na arquitetura do poder interno e supranacional (FARIA, 1996, p. 142 e ss). Por outro lado, a crise do Estado é também uma crise da sociedade e da cidadania, aqui, compreendida como direito a ter direitos humanos e fundamentais efetivos.

A redução dos níveis de prestação social em tempos de crise, a "flexibilização" e mesmo supressão de direitos e garantias dos trabalhadores, o agravamento do desemprego e, portanto, das condições de acesso à fruição dos demais direitos, desafiam mecanismos de superação desse quadro e colocam em cheque a capacidade do Direito e das instituições e procedimentos do Estado Democrático de Direito de atenderem de modo adequado às dificuldades e bloquearem o déficit de efetividade dos direitos fundamentais em geral e dos direitos sociais em particular. Um singelo e conhecido exemplo dos problemas que avultam em tempos de aguda crise econômica diz com a distribuição, pelo Estado, de expressivas quantias em recursos públicos para subsidiar corporações financeiras, ou mesmo a concessão de incentivos fiscais a empreendimentos privados, em detrimento da capacidade de prestação estatal na seara da proteção social, ou ainda - como ocorrido recentemente na Grécia, Espanha e Portugal - o corte até mesmo nos vencimentos de servidores públicos, mantida (eventualmente, inclusive, aumentada) a carga tributária ou o percentual em termos de contribuições sociais.

Aquilo que se pode chamar de uma crise dos direitos fundamentais (mas que também é simultaneamente uma crise dos direitos humanos, compreendidos como aqueles direitos consagrados no âmbito do sistema internacional de direitos humanos), embora seja aparentemente mais aguda na seara dos direitos sociais a prestações, assume, todavia, contornos muito mais amplos, pois afeta os direitos de todas as gerações (ou dimensões), além de não poder ser atribuída exclusivamente ao fenômeno da globalização e mesmo da crise econômica. A amplitude da crise envolve, também, o impacto da tecnologia sobre uma série de direitos de matriz pessoal e individual, como é o caso da privacidade, a afetação do ambiente (natural e do trabalho), entre muitos 
outros aspectos que poderiam ser citados nesse contexto. Por outro lado, percebe-se que a crise econômica e a crescente exclusão social guardam relação (ainda que não exclusiva) com o aumento da criminalidade e, por conseguinte, implica aumento de violação de direitos fundamentais. Assim, além de a crise dos direitos fundamentais não estar restrita aos direitos sociais, também a crise dos direitos sociais atua como fator de impulso e agravamento da crise dos demais direitos.

A referência a uma crise dos direitos fundamentais, com destaque, aqui, para os direitos sociais, assumiria uma feição reducionista se fosse limitada a uma crise de efetividade, em outras palavras, ao fenômeno da ineficácia social do programa jurídico-político dos direitos sociais enquanto direitos humanos e fundamentais ou quando não houver direitos sociais assegurados na Constituição, das normas definidoras de fins e tarefas estatais na esfera socioeconômica e da própria legislação social. Assim, é possível, salvo melhor juízo, a exemplo do que já o fizemos em texto anterior, falar de uma crise de identidade dos direitos sociais (e dos direitos fundamentais) e mesmo de uma crise de reconhecimento e/ou confiança (SARLET, 1999). Com efeito, sob determinada perspectiva, a falta de efetividade dos direitos conduz a uma crescente desvalorização de sua força normativa e na falta de confiança no discurso dos direitos fundamentais, mas também é perceptível uma espécie de polarização entre o segmento populacional que ainda exerce plenamente sua cidadania e goza de direitos efetivos, e aqueles que praticamente estão alijados do acesso à fruição dos direitos que, em tese (e cada vez mais em tese), assumem a condição de direitos de titularidade universal. Apenas a título ilustrativo, vale mencionar que a crescente criminalidade - ao menos é o que se percebe no caso do Brasil, ao qual aqui recorremos - leva a uma elevação da tensão social e acaba por estimular uma opinião pública favorável ao aumento das penas na esfera criminal (inclusive a inserção da pena de morte) e mesmo tolerante em relação à prática da tortura e de métodos de investigação e repressão do crime incompatíveis com o sistema de direitos fundamentais, pelo menos nos moldes do que atualmente é adotado na maioria dos Estados que pretendem ostentar o título de Estados Democráticos de Direito. Outro eixo do problema - mas que está diretamente relacionado (ainda que não exclusivamente, pois a questão do fundamentalismo religioso e do terrorismo assume uma dimensão relevante nesse contexto) ao acirramento da crise econômica em escala global - guarda relação com os movimentos migratórios e o endurecimento das regras sobre concessão de asilo ou abrigo político e/ou econômico e ondas de xenofobia que se manifestam inclusive na esfera política, notadamente no crescimento dos partidos políticos de direita, sem considerar o incremento das tensões sociais. Soma-se a isso a situação dos chamados refugiados ambientais e o impacto da degradação ambiental sobre um contingente imenso de populações, em geral, as mais afetadas pela exclusão social e que, muitas vezes, vivem em situação de risco. Seca, inundações, avalanches e desmoronamentos costumam atingir muito mais os pobres do que os que - embora não imunes - possuem melhores condições de se prevenir e proteger. 
Todo esse quadro de crise, aqui traçado de modo meramente esquemático e ilustrativo, coloca desafios ao Direito e às Instituições que devem zelar pela sua realização prática, levando até mesmo a um repensar da noção de direitos fundamentais, sua função e sua viabilidade na condição de normas de direito objetivo vinculantes e como posições subjetivas exigíveis pelo e em face do Estado e mesmo da sociedade, seja no plano interno dos Estados, seja no plano supranacional. Aqui já se podem enunciar algumas perguntas, as quais, ao menos em parte, serão enfrentadas nos próximos segmentos.

Uma das indagações segue sendo a de como é possível atribuir aos direitos sociais a condição de direitos fundamentais, especialmente, na condição de direitos a prestações fáticas estatais, visto terem a sua efetividade diretamente impactada pela escassez de recursos. Em outras palavras, cuida-se de saber o quanto os direitos a prestações podem ser considerados direitos exigíveis. Tal questão se articula com o problema do regime jurídico dos direitos sociais e da possibilidade de, mediante a determinado regime jurídico (internacional, constitucional, legal), assegurar-se tanto a eficácia e efetividade das normas definidoras de direitos sociais em termos de direitos positivos, portanto, direitos a prestações estatais, quanto assegurar que os níveis vigentes de proteção jurídica dos direitos sociais não sejam esvaziados, mas também - e como decorrência disso - possam contribuir pelo menos para a manutenção de níveis de proteção social compatíveis com a dignidade humana.

Importa sublinhar, ainda, que o desafio da efetividade dos direitos sociais não constitui um privilégio dos direitos sociais na condição de direitos fundamentais, pois, ainda que se cuide de ordens jurídico-constitucionais que tenham renunciado à constitucionalização de tais direitos, optando por um sistema de proteção social de matriz no todo ou em grande parte infraconstitucional, a crise econômica e a escassez de recursos se revela igualmente (pelo menos quanto a determinados aspectos) relevante para os níveis concretos de proteção social assegurados pelos Estados, bastando apontar para os recentes desenvolvimentos na União Europeia, na qual - com ou sem direitos fundamentais sociais nas constituições - a crise econômica tem afetado significativamente as prestações sociais disponibilizadas aos cidadãos, inclusive com reflexos no que diz com tratamentos diferenciados reservados para os estrangeiros, notadamente os considerados em situação irregular. ${ }^{9}$ Por outro lado, também é correto afirmar que a constitucionalização dos direitos sociais na condição de direitos sociais ou, ao menos, a previsão de determinados critérios de matriz constitucional que sirvam de parâmetro para assegurar um controle da legitimidade constitucional das medidas que afetam (para menos) os níveis de proteção social, poderá assumir um papel mais ou menos relevante, sem prejuízo da discussão na esfera da Política e das políticas, que nem

\footnotetext{
9 É o caso, v.g., da Espanha, onde, além dos altíssimos índices de desemprego, redução dos proventos dos servidores públicos, entre outros (assim como ocorreu na Grécia e em Portugal), recentemente está sendo proposta a exclusão dos estrangeiros em situação irregular do sistema público de saúde.
} 
sempre é sensível aos parâmetros constitucionais ou, pelo contrário, acaba por levar a reformas constitucionais e/ou legislativas.

Assim, a partir das considerações precedentes, iremos, nas próximas seções, apresentar algumas considerações sobre a chamada "reserva do possível" (ou da escassez e/ou falta de disponibilidade de recursos, por sua vez, vinculada ao problema do "custo dos direitos") como limite à efetivação dos direitos sociais na condição de direitos exigíveis, passando, na sequência, a tratar do problema das possibilidades e limites de uma proibição de retrocesso (ou regressividade) como instrumento de garantia pelo menos de níveis mínimos de proteção social, tema que - precisamente em razão do agravamento da crise econômica e de suas consequências - cresce em relevância.

\section{Os direitos sociais são (ou seguem sendo) direitos exigíveis? Revisitando alguns aspectos ligados à efetividade dos direitos sociais, em especial, 0 problema da chamada "reserva do possível"}

Mesmo considerando as relevantes diferenças não apenas entre os níveis de efetividade dos direitos sociais (na lei e/ou nas constituições ou por força da ratificação de tratados internacionais) entre os Estados que integram a comunidade internacional, mas também atentando para as diferenças existentes em termos de regime jurídico de reconhecimento, proteção e promoção (inclusive quanto ao papel dos atores estatais e privados nessa seara), o conjunto das objeções que costumam ser referidas quando se trata de definir se e em que medida os direitos sociais podem ser considerados direitos exigíveis - portanto, direitos que geram pretensão de efetividade - pode, em maior ou menor medida, ser considerado comum, o que assume particular relevância quando se cuida do problema do custo dos direitos e da escassez de recursos (aqui tomada sem sentido amplo), mas também dos problemas ligados ao poder de disposição dos recursos, ainda que existentes.

Justamente pelo fato de os direitos sociais na sua condição (como vimos, não exclusiva!) de direitos a prestações terem por objeto prestações estatais vinculadas diretamente à destinação, distribuição (e redistribuição), bem como à criação de bens materiais, aponta-se, com propriedade, para sua dimensão economicamente relevante. Com isso, não se está a afirmar a "irrelevância econômica" dos direitos de defesa (negativos), pois não se desconhece (nem se desconsidera) a noção, largamente difundida, de que todos os direitos fundamentais (inclusive os chamados direitos de defesa), como já afirmava Häberle (1972, p. 76), e, mais recentemente, sustentaram Holmes e Sunstein (1999), são, de certo modo, sempre direitos positivos, no sentido de que também os direitos de liberdade e os direitos de defesa em geral exigem, para sua tutela e promoção, um conjunto de medidas positivas por parte do poder público e que sempre abrangem a alocação significativa de recursos materiais e humanos para sua proteção e efetivação de maneira geral. Assim, não há como negar que todos os direitos fundamentais podem implicar "um custo" de tal 
sorte que essa circunstância não se limita nem aos direitos sociais na sua dimensão de direitos a prestações.

Em que pese tal constatação (e a sua substancial correção), é forçoso reconhecer que, no caso dos direitos sociais a prestações, seu "custo" assume especial relevância no âmbito de sua eficácia e efetivação, ${ }^{10}$ significando, ao menos para grande parte da doutrina, que a efetiva realização das prestações reclamadas não é possível sem que se aloque algum recurso, dependendo, em última análise, da conjuntura econômica, já que aqui está em causa a possibilidade de os órgãos jurisdicionais imporem ao poder público a satisfação das prestações reclamadas. Aliás, não foi outro o entendimento (ainda que mitigado e reinterpretado parcialmente desde então) veiculado no Pacto Internacional de Direitos Econômicos, Sociais e Culturais (1966) - conta atualmente com mais de 160 Estados-Partes - ao estabelecer, diferentemente do Pacto dos Direitos Civis e Políticos, que os direitos sociais geram para os Estados pactuantes um dever de progressiva realização dos direitos assegurados pelo Pacto, na medida das capacidades econômicas de cada Estado (Art. 2, item 1). Além disso, muito embora um direito de defesa (uma liberdade, por exemplo) implique custos e medidas de organização e procedimento, a fruição da dimensão negativa de tais direitos (por exemplo, a concessão de uma ordem de habeas corpus) não costuma ser condicionada a prestações estatais materiais, e nem a chamada reserva do possível é, nesse contexto, invocada pela doutrina como objeção relevante.

Outrossim, muito embora a regra da relevância econômica dos direitos sociais na condição de direitos a prestações possa ser aceita sem maiores reservas, há que questionar, todavia, se efetivamente todos os direitos dessa natureza apresentam dimensão econômica relevante, havendo, nesse contexto, quem sustente a existência de exceções, apontado para direitos sociais a prestações economicamente neutros (por não implicarem a alocação de recursos para sua efetivação), no sentido de que há prestações materiais condicionadas ao pagamento de taxas e tarifas públicas (MURSWIEK, 2000 p. 254), além de outras que se restringem ao acesso aos recursos já disponíveis. É preciso observar, contudo, que, mesmo nas situações apontadas, ressalta uma repercussão econômica ao menos indireta, uma vez que até o já disponível resultou da alocação e aplicação de recursos, sejam materiais, humanos ou financeiros em geral, oriundos, em regra, da receita tributária e outras formas de arrecadação do Estado ou dependentes, quando se trata do repasse dos encargos aos atores sociais, dos níveis de emprego e remuneração.

Diretamente vinculada a essa característica dos direitos fundamentais sociais a prestações está a problemática da efetiva disponibilidade do seu objeto, isto é, se o destinatário da norma se encontra em condições de dispor da prestação reclamada (isto é, de prestar o que a norma lhe impõe seja prestado), encontrando-se, portanto, na dependência da real existência dos meios para cumprir com sua obri-

${ }_{10}$ Neste sentido também, entre outros, Silva (2008, p. 591 e ss.). 
gação. Já há tempo se averbou que o Estado dispõe apenas de limitada capacidade de dispor sobre o objeto das prestações reconhecidas pelas normas definidoras de direitos fundamentais sociais (BRUNNER, 1971, p. 14 e ss), de tal sorte que a limitação dos recursos, segundo alguns, opera como autêntico limite fático à efetivação desses direitos. ${ }^{11}$ Distinta (embora conexa) da disponibilidade efetiva dos recursos, ou seja, da possibilidade material de disposição, situa-se a problemática ligada à possibilidade jurídica de disposição, já que o Estado (assim como o destinatário em geral) também deve ter a capacidade jurídica, em outras palavras, o poder de dispor, sem o qual de nada lhe adiantam os recursos existentes..$^{12}$ Encontramo-nos, portanto, diante de duas facetas diversas, porém, intimamente entrelaçadas, que caracterizam os direitos fundamentais sociais a prestações. É justamente em virtude desses aspectos que se passou a sustentar a colocação dos direitos sociais a prestações sob o que se convencionou designar de uma "reserva do possível", que, compreendida em sentido amplo, abrange mais do que a ausência de recursos materiais propriamente ditos indispensáveis à realização dos direitos na sua dimensão positiva.

A utilização da expressão "reserva do possível" (associada à noção de escassez e da disponibilidade de recursos), ao que se sabe, tem origem na Alemanha, especialmente a partir do início dos anos 1970 (CANOTILHO, 1999, p. 108). De acordo com a noção de reserva do possível, a efetividade dos direitos sociais a prestações materiais estaria sob a reserva das capacidades financeiras do Estado, uma vez que seriam direitos fundamentais dependentes de prestações financiadas pelos cofres públicos. A partir disso, a "reserva do possível" (Der Vorbehalt des Möglichen) passou a traduzir (tanto para a doutrina majoritária quanto para a jurisprudência constitucional na Alemanha) a ideia de que os direitos sociais a prestações materiais dependem da real disponibilidade de recursos financeiros por parte do Estado, disponibilidade essa que estaria localizada no campo discricionário das decisões governamentais e parlamentares, sintetizadas no orçamento público. Tais noções foram acolhidas e desenvolvidas na jurisprudência do Tribunal Constitucional Federal da Alemanha, que, desde o paradigmático caso numerus clausus, versando sobre o direito de acesso ao ensino superior, firmou entendimento no sentido de que a prestação reclamada deve corresponder àquilo que o indivíduo pode razoavelmente exigir da sociedade, pois, mesmo dispondo o Estado dos recursos e tendo o poder de disposição, não se pode falar em uma obrigação de prestar algo que não se mantenha nos limites do razoável. ${ }^{13}$ Assim, poder-se-ia sustentar que não haveria como impor ao Estado a prestação de assistência social a alguém que efetivamente não faça jus ao benefício, por dispor, ele próprio, de recursos suficientes para seu sustento. $\mathrm{O}$

\footnotetext{
11 Esta, entre outras, a lição de Starck (1976, p. 518).

12 A esse respeito, ver também Brunner (1971, p. 16). Tal dimensão cresce em relevo se considerarmos o problema da repartição de competência no âmbito do Estado Federal e, acima de tudo, na repartição das receitas tributárias e sua afetação e aplicação, temática que aqui não há como desenvolver.

13 Conforme Entscheidungen des Bundesverfassungsgericht, vol. 33, p. 303 e ss., especialmente p. 333 e ss.
} 
que, contudo, corresponde ao razoável também depende - de acordo com a decisão referida e boa parte da doutrina alemã - da ponderação por parte do legislador (WIEGAND, 1974, p. 657).

A partir do exposto, há como sustentar que a designada reserva do possível, especialmente se compreendida em sentido mais amplo, apresenta pelo menos uma dimensão tríplice, que abrange a efetiva disponibilidade fática dos recursos para a efetivação dos direitos fundamentais; a disponibilidade jurídica dos recursos materiais e humanos, que guarda íntima conexão com a distribuição das receitas e competências tributárias, orçamentárias, legislativas e administrativas, entre outras, e que, além disso, reclama especial equacionamento - como ocorre no caso do Brasil - no contexto do sistema constitucional federativo, mas também assume relevância em modelos de Estado como o da Espanha, que assegura ampla autonomia para as comunidades autônomas, que chegam a contemplar direitos sociais não previstos na Constituição Espanhola; já na perspectiva (também) do eventual titular de um direito a prestações sociais, a reserva do possível envolve o problema da proporcionalidade da prestação, em especial, no tocante à sua exigibilidade e, nessa quadra, também da sua razoabilidade.

Importa frisar que todos os aspectos referidos guardam vínculo estreito entre si e com outros princípios constitucionais (por exemplo, os da igualdade, subsidiariedade e solidariedade), exigindo, além disso, um equacionamento sistemático e constitucionalmente adequado, para que, na perspectiva de um dever de assegurar a máxima eficácia e efetividade dos direitos fundamentais sociais (ainda que não consagrados propriamente como tais, pois, em geral, aos Estados incumbe, já por força dos tratados internacionais, dever de progressiva realização dos direitos sociais), possam servir não como barreira instransponível, mas, inclusive, como ferramental para a garantia também dos direitos sociais de cunho prestacional.

O que se pode afirmar, em apertada síntese, é que a objeção (ou noção) da reserva do possível constitui, em verdade (considerada toda a sua complexidade), espécie de limite jurídico e fático dos direitos fundamentais, mas também poderá atuar, em determinadas circunstâncias, como garantia dos direitos fundamentais, por exemplo, na hipótese de conflito de direitos, quando se cuidar da invocação desde que observados os critérios da proporcionalidade e da garantia do mínimo existencial em relação a todos os direitos fundamentais - da indisponibilidade de recursos com o intuito de salvaguardar o núcleo essencial de outro direito fundamental (SARLET, 2009b, p. 354 e ss.).

Nesse contexto, há quem sustente que, por estar em causa uma verdadeira opção quanto à afetação material dos recursos, também há de ser tomada uma decisão sobre a aplicação destes, que, por sua vez, depende da conjuntura socioeconômica global, partindo-se, nesse sentido, da premissa de que a Constituição não oferece, ela mesma, os critérios para essa decisão, deixando-a a cargo dos órgãos políticos (de modo especial ao legislador) competentes para a definição das linhas gerais das políticas na esfera socioeconômica (ANDRADE, 1987, p. 200 e ss). É justamente por 
essa razão que a realização dos direitos sociais na sua condição de direitos subjetivos a prestações - de acordo com oportuna lição de Canotilho (1982, p. 369) - costuma ser encarada como sendo sempre também um autêntico problema em termos de competências constitucionais, pois, segundo averba o autor referido, "[...] ao legislador compete, dentro das reservas orçamentais, dos planos económicos e financeiros, das condições sociais e económicas do país, garantir as prestações integradoras dos direitos sociais, económicos e culturais."

Como atende a problemática posta pelos que apontam para um "custo dos direitos" (por sua vez, indissociável da designada "reserva do possível"), a crise de efetividade vivenciada com cada vez maior agudeza pelos direitos fundamentais sociais a prestações (assim como dos direitos sociais legislativamente concretizados) está diretamente conectada com a maior ou menor carência de recursos disponíveis para o atendimento das demandas em termos de políticas sociais (SARLET; TIMM, 2010). Com efeito, quanto mais diminuta a disponibilidade de recursos, mais se impõe uma deliberação responsável a respeito de sua destinação, o que nos remete diretamente à necessidade de buscarmos o aprimoramento dos mecanismos de gestão democrática do orçamento público, assim como do próprio processo de administração das políticas públicas em geral, seja no plano da atuação do legislador, seja na esfera administrativa, ${ }^{14}$ seja no concernente à eventual ampliação do acesso à justiça como direito a ter direitos capazes de serem efetivados, o que, por sua vez, guarda relação com a discussão em torno das possibilidades e limites do controle judicial das políticas públicas em matéria de direitos sociais e do reconhecimento de direitos a prestações sociais de caráter originário e derivado ${ }^{15}$ (no sentido de direitos de igual acesso às prestações disponibilizadas pelo poder público). ${ }^{16} \mathrm{O}$ quanto uma postura proativa dos órgãos jurisdicionais se revela produtiva para assegurar a efetividade dos direitos sociais na condição de direitos exigíveis, tem sido objeto de intenso debate na literatura especializada, verificando-se, também, nessa seara, uma diversidade significativa no se refere à prática judiciária dos diferentes países, diversidade que abrange desde modelos de praticamente completa retração judicial na matéria (o Poder Judiciário não reconhece direitos sociais como direitos exigíveis) até modelos de forte intervenção judicial, como no caso do Brasil e da Colômbia, onde se registram centenas de milhares de ações judiciais, grande parte acolhida pelo Poder Judiciário e resultando na imposição de obrigações positivas aos respectivos governos. ${ }^{17}$

\footnotetext{
14 Conforme Leal (2006, p. 57 e ss.), cuidando do tema à luz da teoria discursiva e da concepção de uma democracia deliberativo-procedimental de matriz Habermasiana.

15 Sobre a distinção entre direitos originários a prestações (direitos subjetivos fundamentados diretamente na Constituição) e direitos derivados a prestações (direitos de igual acesso às prestações já concretizadas pelo legislador e na esfera das políticas públicas estatais) ver Martens (1972, p. 7 e ss.).

16 Sobre o problema da exigibilidade dos direitos sociais, em uma perspectiva do direito internacional e comparado, ver por todos, Abramovich e Courtis (2004). Mais recentemente, ver Courtis e Santamaría (2009).

17 Sobre o tema, em caráter exemplificativo, a partir do exemplo do direito à saúde, Yamin e Gloppen (2011), destacando-se os capítulos 4 e 5, contemplando os casos do Brasil e da Colômbia, bem como, em uma perspectiva mais ampliada, a obra coletiva editada por Courtis e Santamaría, citada na nota anterior, bem como a recente obra de King (2012).
} 
Independentemente da necessidade de maior desenvolvimento do tema, que, aqui, não se revela possível, há que dar razão a Holmes e Sunstein (1999) quando afirmam que levar direitos a sério (especialmente pelo prisma da eficácia e efetividade) é sempre também levar a sério o problema da escassez ${ }^{18}$. Precisamente por tal razão é de se apostar em estratégias de litigância - ou de ação - (não, necessariamente, judicial) aptas a assegurar, ao menos, níveis de prestação sociais compatíveis com as exigências mínimas da dignidade humana. Parece-nos oportuno apontar (mesmo sem condições de desenvolver o ponto) que os princípios da moralidade e eficiência (nem sempre previstos no plano constitucional, como ocorre no caso do Brasil, mas habitualmente - e de algum modo - presentes nos sistemas jurídicos), mas também os correlatos princípios (e deveres) de publicidade e transparência, que direcionam a atuação da administração pública em geral, assumem um papel de destaque nessa discussão, notadamente quando se cuida de administrar a escassez de recursos e potencializar a efetividade dos direitos sociais.

Precisamente nesse contexto, é possível referir recente decisão do Tribunal Constitucional Federal da Alemanha, datada de 09 de fevereiro de 2010, versando sobre a legitimidade constitucional de reforma no sistema de proteção social, em que aspectos de ampla reforma legislativa do código de proteção social (a chamada legislação Hartz IV), foram declarados incompatíveis com a ordem social, pois estariam - entre outros pontos - afetando a garantia do mínimo existencial, além de o legislador não ter observado o seu dever de transparência, deixando de demonstrar de forma clara e acessível ao cidadão, os critérios que levaram ao estabelecimento do valor dos benefícios sociais. ${ }^{19}$

Ainda nessa perspectiva, em virtude da íntima conexão dessa problemática com a discussão em torno da designada "reserva do possível", na condição de limite fático e jurídico à efetivação judicial (e até mesmo política) de direitos fundamentais - e não apenas dos direitos sociais, consoante já frisado - vale destacar que também resta abrangida na obrigação de todos os órgãos estatais e agentes políticos a tarefa de maximizar os recursos e minimizar o impacto da reserva do possível. Isso significa, em primeira linha, que se a reserva do possível há de ser encarada com reservas (FREITAS, 2002, p. 211), também é certo que as limitações vinculadas à reserva do possível não são, em si mesmas, necessariamente, uma falácia. O que tem sido, de fato, falaciosa, é a forma pela qual, muitas vezes, a reserva do possível tem sido utilizada como argumento impeditivo da intervenção judicial e desculpa genérica para a omissão estatal no campo da efetivação dos direitos fundamentais, especialmente de cunho social.

Levar a sério a "reserva do possível" (e ela deve ser levada a sério, embora sempre com as devidas reservas) significa também, especialmente - mas não ex-

\footnotetext{
18 Conforme Holmes e Sunstein (1999, p. 94), ("Taking rights seriously means taking scarcity seriously"), bem como, de modo geral, p. 87 e ss., em que os autores demonstram como a escassez afeta as liberdades e discutem o papel do Poder Judiciário na imposição de encargos ao poder público notadamente no que diz com a alocação dos recursos.

19 Conforme BVerfGE, vol. 125, p. 175 e ss.
} 
clusivamente! - que cabe ao poder público o ônus da comprovação da falta efetiva dos recursos indispensáveis à satisfação dos direitos a prestações, assim como da eficiente aplicação deles (PIRARELLO, 2007, p. 201). Da mesma forma, assume relevo o já referido princípio da proporcionalidade, que deverá presidir a atuação dos órgãos estatais e dos particulares, seja quando exercem função tipicamente estatal, mesmo que de forma delegada (com destaque para a prestação de serviços públicos), seja aos particulares de um modo geral. Além disso, nunca é demais recordar que a proporcionalidade haverá de incidir na sua dupla dimensão como proibição do excesso (de intervenção) e de insuficiência (de proteção), além de, nessa dupla acepção, atuar sempre como parâmetro necessário de controle dos atos do poder público, inclusive dos órgãos jurisdicionais, igualmente vinculados pelo dever de proteção e efetivação dos direitos fundamentais. Isso significa, em apertadíssima síntese, que os responsáveis pela efetivação de direitos fundamentais, inclusive e especialmente no caso dos direitos sociais, em que a insuficiência de proteção e promoção (em virtude da omissão plena ou parcial do legislador e administrador) causa impacto mais direto e expressivo, deverão observar os critérios parciais da adequação (aptidão do meio no que diz com a consecução da finalidade almejada), da necessidade (menor sacrifício do direito restringido) e da proporcionalidade em sentido estrito (avaliação da equação custo-benefício - para alguns, da razoabilidade no que diz com a relação entre os meios e os fins), respeitando sempre o núcleo essencial do(s) direito(s) restringido(s), mas também não poderão, a pretexto de promover algum direito, desguarnecer a proteção de outro(s) no sentido de ficar aquém de um patamar minimamente eficiente de realização e de garantia do direito.

Outro caminho a ser trilhado (ou aperfeiçoado) diz respeito ao controle judicial e social das opções orçamentárias e da legislação relativa aos gastos públicos em geral (inclusive da que dispõe sobre a responsabilidade fiscal), já que com isso se poderá, também, minimizar os efeitos da reserva do possível, notadamente no que diz com sua componente jurídica, considerando a possibilidade (ainda que manuseada com saudável e necessária cautela) de redirecionar recursos (ou mesmo suplementá-los) no âmbito dos recursos disponíveis e, importa frisar, disponibilizáveis. Com efeito, o que se verifica, em muitos casos, é uma inversão hierárquica tanto em termos jurídico-normativos quanto em termos axiológicos, quando se pretende bloquear qualquer possibilidade de intervenção nesse plano, a ponto de se privilegiar a legislação orçamentária em detrimento de imposições e prioridades constitucionais ${ }^{20} \mathrm{e}$, o que é mais grave, prioridades em matéria de efetividade de direitos fundamentais. Tudo está a demonstrar que a designada reserva do possível não pode ser

\footnotetext{
${ }_{20}$ Nesse sentido, ver, dentre tantos, Krell (2002), com ampla argumentação, bem como Leal (2005, p. 157 e ss.), que lembra a existência de políticas públicas constitucionais vinculantes, o que, é claro - é necessário acrescentar - não poderá ser automaticamente estendido a qualquer sistema constitucional, embora seja possível afirmar que a ausência de inclusão no orçamento público da previsão de atendimento de demandas sociais básicas também viola o sistema internacional de direitos humanos, ainda mais quando em causa o chamado mínimo existencial.
} 
pura e simplesmente reduzida a um limite posto pelo orçamento, até porque, se fosse assim, um direito social sob "reserva de cofres cheios" equivaleria, na prática - como diz Canotilho (apud GRAU, 2005, p. 125) - a nenhuma vinculação jurídica.

Além disso, o eventual impacto da reserva do possível certamente poderá ser, se não completamente neutralizado, pelo menos minimizado, mediante o controle (também jurisdicional!) das decisões políticas acerca da alocação de recursos, inclusive no que diz com a transparência das decisões e a viabilização do controle social sobre a aplicação dos recursos alocados no âmbito do processo político. ${ }^{21}$ Uma vez que a possibilidade de satisfação dos direitos reconhecidos pela Constituição (e também na esfera da legislação infraconstitucional) guarda vinculação com escolhas estratégicas sobre qual a melhor forma de aplicar os recursos públicos, como recordam Holmes e Sunstein (1999), há, de fato, boas razões de ordem democrática a indicarem que as decisões sobre quais direitos efetivar (bem como sobre em que medida se deve fazê-lo!) devam ser feitas do modo mais aberto possível e com a garantia dos níveis mais efetivos de informação da população, destinatária por excelência das razões e justificativas que devem sustentar as decisões tanto dos agentes políticos em geral quanto dos juízes. ${ }^{22}$

No que diz com a atuação do Poder Judiciário, não há como desconsiderar o problema da sua prudente e responsável autolimitação funcional (do designado judicial self restraint), que evidentemente deve estar sempre em sintonia com a sua necessária e já afirmada legitimação para atuar, de modo proativo, no controle dos atos do poder público em prol da efetivação ótima dos direitos (de todos os direitos) fundamentais. Que a atuação dos órgãos jurisdicionais - sempre provocada - não apenas não dispensa, como, inclusive, exige uma contribuição efetiva dos demais atores políticos e sociais, como é o caso do Ministério Público, das Agências Reguladoras, dos Tribunais de Contas, das organizações sociais de um modo geral, bem como dos cidadãos individualmente considerados, resulta evidente, mas nem sempre corresponde a uma prática institucional efetiva nessa seara. Da mesma forma, imprescindível, como bem aponta relevante doutrina, maior investimento na análise do perfil (e da capacidade) institucional do Poder Judiciário na esfera da promoção da justiça social e, portanto, a importância de se instaurar um autêntico diálogo interinstitucional ${ }^{23}$, que, por sua vez, passa pelo respeito ao princípio e correspondente

\footnotetext{
${ }^{21}$ Conforme Comparato (2003, p. 256-257). Em sentido similar, bem destacando e desenvolvendo diversas das questões vinculadas ao controle de políticas públicas e o problema do controle das normas orçamentárias, ver Barcellos (2006, p. 17-54).

${ }^{22}$ Segue texto original em inglês no qual embasamos, com ajustes, o nosso entendimento: "Because rights result from strategic choices about how best to deploy public resources, there are good democratic reasons why decisions about which rights to protect, and to what degree, should be made in as open a manner as possible by a citizenry as informed as possible, to whom political officials, including judges, must address their reasonings and justifications." (HOLMES; SUNSTEIN, 1999, p. 227).

${ }^{23}$ Nesse sentido, ver, em especial, discorrendo sobre a ótica da promoção da justiça distributiva por meio da atuação do Poder Judiciário, Lopes (2006, p. 185 e ss.), bem como Binenbojm e Cyrino (2008, p. 997 e ss.), chegando a apontar para uma "virada institucional". Na mesma linha e contidos na mesma obra coletiva, ver, ainda, os já referidos aportes de Barroso, Sarmento e Souza Neto.
} 
dever de cooperação. Também nesse contexto assumem relevo os princípios da moralidade e probidade da administração pública, de tal sorte que - mesmo sem desenvolver o ponto - é possível afirmar que a maximização da eficácia e efetividade de todos os direitos fundamentais, na sua dupla dimensão de direitos de defesa e direitos a prestações, depende, em parte significativa, da otimização do direito fundamental a uma boa (e, portanto, sempre proba e moralmente vinculada) administração.

Ainda em relação à objeção da escassez de recursos, consideramos oportuna a referência ao pensamento de Novais $(2004$, p. 295) ao afirmar que a reserva do possível (antes de atuar como barreira intransponível à efetivação dos direitos fundamentais, importa acrescentar!) deve operar como uma espécie de mandado de otimização da eficácia e efetividade dos direitos fundamentais, impondo ao Estado atentando para as peculiaridades da ordem jurídico-constitucional e mesmo de seu respectivo contexto socioeconômico - o dever fundamental de, tanto quanto possível, promover as condições ótimas de efetivação da prestação estatal em causa, preservando, além disso, os níveis de realização já atingidos, o que, por sua vez, aponta para a necessidade do reconhecimento de uma proibição do retrocesso, ainda mais naquilo que se está a preservar: o mínimo existencial e/ou conteúdo essencial dos direitos fundamentais sociais, aspecto que será abordado logo a seguir.

Nessa mesma perspectiva, calha ainda invocar o entendimento de Strapazzon (2012, p. 49-73), que também aponta para o que se poderia designar de "sentido positivo da reserva do possível", argumentando que a própria Constituição Federal (CF) sustenta não apenas uma reserva constitucional expressa de receitas tributárias para determinados direitos sociais (saúde e educação), como também estabelece a separação entre o orçamento fiscal e o da seguridade social, o que, embora não diga respeito a todos os direitos sociais, pelo menos vale para os domínios da assistência social, previdência, saúde e educação, que representam boa parte dos principais direitos sociais e mesmo das exigências de um mínimo existencial. Da mesma forma, assume relevo, no mesmo contexto, a demanda em torno do tema do adequado financiamento dos direitos sociais, do controle da efetividade em termos dos gastos mínimos, do caráter progressivo e não regressivo de tais gastos e do caráter vinculativo da execução do orçamento e da vinculação das receitas, apenas para referir alguns dos aspectos mais problemáticos e que se encontram na ordem do dia do debate político e acadêmico ${ }^{24}$.

\section{A proibição de retrocesso (ou de regressividade) em matéria de direitos sociais como caso especial de garantia dos níveis de prestação social}

Crise econômica e instabilidade quanto aos níveis de segurança social não constituem fenômenos recentes, mas no âmbito da globalização econômica e sob o

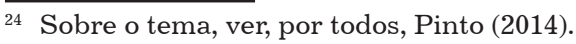


domínio do capitalismo financeiro alcançaram particular amplitude e repercussão, transformando-se em problema dos diversos Estados e da comunidade internacional. O quanto instrumentos jurídicos são capazes de prevenir ou mesmo coibir os efeitos da crise, especialmente, para o que interessa ao nosso propósito, no que impactam a efetividade dos direitos sociais a prestações, é tema que, aqui, não será possível desenvolver. De todo modo, é correto afirmar que como instância regulatória o Direito prevê mecanismos que podem pelo menos contribuir para alguns efeitos. Considerando o dever de progressividade (no sentido da progressiva realização dos direitos sociais) imposto aos Estados por força especialmente do Pacto Internacional de Direitos Econômicos, Sociais e Culturais, há muito a doutrina e também a jurisprudência apontam, seja no plano do sistema internacional de proteção dos direitos humanos, seja na esfera interna das diferentes ordens jurídico-constitucionais, a existência de um princípio de proibição de regressividade ou, como preferem outros, de proibição de retrocesso social ${ }^{25}$.

Desde logo importa sublinhar que a noção de uma proibição de retrocesso se encontra relacionada ao princípio da segurança jurídica e dos seus respectivos desdobramentos (princípio da proteção da confiança e as garantias constitucionais do direito adquirido, do ato jurídico perfeito e da coisa julgada), bem como - a depender das características de cada ordem constitucional - guarda conexão com os limites materiais à reforma constitucional, considerando que tais institutos também objetivam a tutela de direitos e bens de matriz constitucional em face de atos e/ou medidas de caráter retroativo ou que venham, de algum modo, afetar situações e posições jurídicas.

A proibição de retrocesso, nesse cenário, diz respeito, mais especificamente, a uma garantia de proteção dos direitos fundamentais sociais (e da própria dignidade da pessoa humana) contra a atuação do legislador, tanto no âmbito constitucional quanto - e de modo especial - infraconstitucional (quando estão em causa medidas legislativas que impliquem supressão ou restrição no plano das garantias e dos níveis de tutela dos direitos já existentes), mas também proteção em face da atuação da administração pública. Outrossim, constata-se que, embora nem sempre sob esse rótulo, tal noção já foi recepcionada no âmbito do constitucionalismo de diversos países e, em perspectiva mais ampla, no cenário constitucional latino-americano e mesmo em alguns países europeus, sem prejuízo da evolução na esfera do direito internacional. ${ }^{26}$

Em uma primeira aproximação da noção de proibição de retrocesso, embora não limitada a tal aspecto, afirma-se que em relação a qualquer norma constitucional (ainda que se trate de norma impositiva de uma tarefa ou objetivo esta-

\footnotetext{
${ }^{25}$ Sobre a proibição de retrocesso em matéria de direitos fundamentais, especialmente no caso dos direitos sociais, ver Sarlet (2009b, p. 433-457). No que diz com a produção monográfica nacional, especificamente dedicada ao tema da proibição de retrocesso social, destacam-se as obras de Derbli (2007); Conto (2008); Fileti (2009) e Pinho e Neto (2010). Por último, ver Miozzo (2010).

${ }^{26}$ Conforme por todos, a obra coletiva de Courtis (2006).
} 
tal em matéria social), existe um direito subjetivo negativo, ou seja, a possibilidade de impugnação de qualquer medida contrária aos parâmetros estabelecidos pela normativa constitucional, o que aponta para a noção de uma proibição de atuação contrária às imposições constitucionais, tal qual adotada no âmbito da proibição de retrocesso. Assim, independentemente da exigibilidade dos direitos sociais na sua condição de direitos positivos, ou seja, de direitos subjetivos a prestações de caráter fático ou normativo, no âmbito da designada eficácia negativa se está em face de uma importante possibilidade de exigibilidade judicial de tais direitos como direitos subjetivos de defesa, em outros termos, como proibições de intervenção ou proibições de eliminação de determinadas posições jurídicas já consolidadas. ${ }^{27}$ Em linhas gerais, portanto, é possível afirmar que a garantia da proibição de retrocesso tem por escopo preservar o bloco normativo - constitucional e infraconstitucional - já construído e consolidado no ordenamento jurídico, especialmente naquilo em que objetiva assegurar a fruição dos direitos fundamentais, impedindo ou assegurando o controle de atos que venham a provocar a supressão ou restrição dos níveis de efetividade vigentes nos direitos fundamentais. É precisamente nesse sentido que se situa a lição dos professores portugueses Canotilho e Moreira (1991, p. 131), as normas constitucionais que reconhecem direitos sociais de caráter positivo implicam uma proibição de retrocesso, já que "[...] uma vez dada satisfação ao direito, este se transforma, nessa medida, em direito negativo, ou direito de defesa, isto é, num direito a que o Estado se abstenha de atentar contra ele."

Seguindo tal entendimento, não é possível, portanto, admitir-se uma ausência de vinculação do legislador (bem como dos órgãos estatais em geral) às normas de direitos sociais (e também dos direitos ecológicos ou socioambientais), assim como, ainda que em medida diferenciada, às normas constitucionais impositivas de fins e tarefas em matéria de justiça social, pois, se assim fosse, estar-se-ia chancelando uma fraude à Constituição, pois o legislador - que ao legislar em matéria de proteção social (e ecológica) apenas está a cumprir um mandamento do Constituinte - poderia pura e simplesmente desfazer o que fez no estrito cumprimento da Constituição. Com efeito, o que está em causa é que o legislador não pode simplesmente eliminar as normas (legais) que concretizam os direitos fundamentais, pois isso equivaleria a subtrair às normas constitucionais a sua eficácia jurídica, já que o cumprimento de um comando constitucional acaba por se converter em uma proibição de destruir a situação instaurada pelo legislador (MIRANDA, 1993, p. 341). Em outras palavras, mesmo considerando que o espaço de prognose e de decisão dos órgãos legislativos é variável, ainda mais no marco dos direitos sociais e das políticas públicas para a sua realização, ${ }^{28}$ não

\footnotetext{
${ }_{27}$ Ver por todos Sarlet (2009b, p. 444 e ss.).

28 Queiroz (2006, p. 75). Desenvolvendo o tópico no âmbito da proibição de retrocesso, ver, da mesma autora, O princípio da não reversibilidade dos direitos fundamentais sociais (2006, p. 83 e ss.), em especial no tocante à vinculação do legislador aos direitos sociais.
} 
se pode admitir que em nome da liberdade de conformação do legislador o valor jurídico de tais direitos acabe sendo esvaziado (NOVAIS, 2006, p. 190).

Assim, resulta perceptível, portanto, que a proibição de retrocesso atua como baliza para a impugnação de medidas que impliquem supressão ou restrição de direitos fundamentais (liberais, sociais e ecológicos) e que possam ser compreendidas como efetiva violação de tais direitos, os quais, por sua vez, também não dispõem de uma autonomia absoluta no sistema constitucional, sendo, em boa parte e em níveis diferenciados, concretizações da própria dignidade da pessoa humana. Assim, na sua aplicação concreta, isto é, na aferição da existência, ou não, de uma violação da proibição de retrocesso, não se poderiam - como, de resto, tem evidenciado toda a produção jurisprudencial sobre o tema - dispensar critérios adicionais, como é o caso da proteção da confiança (a depender da situação concreta, é claro), da dignidade da pessoa humana e do correlato mínimo existencial (social e socioambiental), do núcleo essencial dos direitos fundamentais, da proporcionalidade, apenas para citar os mais relevantes e que, no seu conjunto, asseguram a devida operatividade à noção de proibição de retrocesso no plano jurídico-constitucional.

$\mathrm{Na}$ esfera dos fundamentos jurídicos da proibição de retrocesso há que destacar - pela sua amplitude -, visto que vincula expressiva maioria dos Estados, a já referida cláusula de progressividade ou o dever de progressiva realização (e proteção) prevista no Pacto Internacional dos Direitos Econômicos, Sociais e Culturais, de 1966, que impõe aos Estados pactuantes a implementação progressiva dos direitos sociais nele consagrados. Dispõe o art. $2^{\circ}, \S 1^{\circ}$, do Pacto que

[...] cada Estado-parte no presente Pacto compromete-se a adotar medidas tanto por esforço próprio como pela assistência e cooperação internacionais, principalmente nos planos econômico e técnico, até o máximo de seus recursos disponíveis, que visem a assegurar, progressivamente, por todos os meios apropriados, o pleno exercício dos direitos reconhecidos no presente Pacto, incluindo, em particular, a adoção de medidas legislativas.

Também o art. 26 da Convenção Americana sobre Direitos Humanos (1969), complementado pelo art. $1^{\circ}$ do Protocolo de San Salvador Adicional à Convenção Americana sobre Direitos Humanos em Matéria de Direitos Econômicos, Sociais e Culturais (1988), prevê o "desenvolvimento progressivo" dos direitos econômicos, sociais e culturais. Em outras palavras, a cláusula de progressividade veicula a necessidade de a proteção e promoção dispensada aos direitos sociais pelo legislador (mas também pelo administrador) ser permanentemente aprimorada e fortificada, vinculando juridicamente os Poderes Públicos à consecução de tal objetivo. Assim, a garantia constitucional da proibição de retrocesso contempla dois conteúdos normativos que se complementam: por um lado, impõe-se ao Estado a obrigação de "não piorar" as condições normativas e fáticas existentes em determinado ordenamento jurídico - e o mesmo vale para a estrutura organizacional-administrativa; por outro lado, também se faz imperativo, especialmente relevante no contexto da proteção do ambiente, uma obrigação de "melhorar", ou seja, de aprimorar tais condições 
normativas - e também fáticas - no sentido de assegurar um contexto cada vez mais favorável ao desfrute de uma vida digna e saudável pelo indivíduo e pela coletividade como um todo 29 .

Sem que se possa, aqui, desenvolver a fundamentação jurídica (internacional e constitucional) do princípio da proibição de retrocesso em matéria de direitos sociais, é possível partir da premissa de que por força da proibição de retrocesso, não é possível engessar a ação legislativa e administrativa, portanto, não é possível impedir ajustes e mesmo restrições. Do contrário - e quanto ao ponto se dispensam maiores considerações - a proibição de retrocesso poderia até mesmo assegurar aos direitos sociais uma proteção mais reforçada do que a habitualmente empregada para os direitos civis e políticos, em que, em princípio, se parte do pressuposto de que não existem direitos absolutamente imunes a qualquer tipo de restrição, mormente para salvaguarda eficiente (do contrário, incidiria a proibição de proteção insuficiente) de outros direitos fundamentais e bens de valor constitucional. ${ }^{30}$

Nessa perspectiva, verifica-se que a doutrina especializada (com reflexos em decisões judiciais) tem sustentado o ponto de vista de que sobre qualquer medida que venha provocar alguma diminuição nos níveis de proteção (efetividade) dos direitos socioambientais recai a suspeição de sua ilegitimidade jurídica, portanto, na gramática do Estado Constitucional, de sua inconstitucionalidade, acionando, assim, um dever no sentido de submeter tais medidas a um rigoroso controle de constitucionalidade ${ }^{31}$ no qual assumem importância os critérios da proporcionalidade (na sua dupla dimensão anteriormente referida), da razoabilidade e do núcleo essencial (com destaque para o conteúdo "existencial") dos direitos sociais, sem prejuízo de outros critérios, como é o da segurança jurídica e dos seus respectivos desdobramentos. Assim, ganha destaque a noção de que no campo da edição de atos legislativos e administrativos que afetam o âmbito de proteção dos direitos sociais, é preciso ter sempre presente que tanto o legislador quanto o administrador se encontram vinculados às proibições de excesso e de insuficiência de proteção, portanto, deverão observar as exigências internas da proporcionalidade, quais sejam, da adequação, da necessidade e da proporcionalidade em sentido estrito, bem como da razoabilidade, que neste artigo não serão objeto de aprofundamento. ${ }^{32}$

De outra parte, também é perceptível que reduzir a proibição de retrocesso a um mero controle da razoabilidade e proporcionalidade, bem como de uma adequada justificação das medidas restritivas, poderá não ser o suficiente, ainda mais se ao controle da proporcionalidade não for agregada a noção de que qualquer medida restritiva deverá preservar o núcleo (ou conteúdo essencial) do direito fundamental

\footnotetext{
${ }_{29}$ Sobre dupla face da proibição de retrocesso social, notadamente em relação às obrigações de "progresso" e "não regressividade", ver Abramovich e Courtis (2004, p. 93-94).

30 Nesse sentido, ver Sarlet (2009b, p. 190).

31 Conforme, por todos, Courtis (2006, p. 29 e ss.).

32 Aqui remetemos, para maior desenvolvimento, entre outros, a Sarlet (2009, p. 394 e ss.) (capítulo sobre os limites aos limites dos direitos fundamentais).
} 
afetado, o que, por sua vez, guarda relação com a opção, no que diz com os limites aos limites dos direitos fundamentais, entre a teoria externa e a teoria interna, sem prejuízo de outros aspectos relevantes a serem considerados e que aqui não serão desenvolvidos. É precisamente neste contexto, no que diz com o alcance da proteção assegurada por conta de uma proibição de retrocesso, que a dignidade da pessoa humana e o designado mínimo existencial (assim como a garantia do núcleo essencial dos direitos fundamentais sociais, que não se confundem - ao menos, não necessariamente - com a noção de mínimo existencial) podem assumir particular relevância, como tem apontado relevante doutrina e jurisprudência. ${ }^{33}$

Por certo, é nessa perspectiva que se colaciona a lição de Canotilho (1999), sustentando que o núcleo essencial dos direitos sociais concretizado pelo legislador (o que não quer dizer que o núcleo essencial se restrinja a tal dimensão) se encontra constitucionalmente garantido contra medidas estatais que, na prática, resultem na anulação, revogação ou aniquilação pura e simples desse núcleo essencial, de tal sorte que a liberdade de conformação do legislador e a inerente autorreversibilidade encontram limitação no núcleo essencial já realizado (CANOTILHO, 1999, p. 338 e ss). O legislador (como o poder público em geral) não pode, portanto, uma vez concretizado determinado direito social no plano da legislação infraconstitucional, mesmo com efeitos meramente prospectivos, voltar atrás e, mediante uma supressão ou mesmo relativização (no sentido de uma restrição), afetar o núcleo essencial legislativamente concretizado de determinado direito socioambiental constitucionalmente assegurado. Assim, é em primeira linha o núcleo essencial dos direitos sociais que vincula o poder público no âmbito de uma proteção contra o retrocesso e que, portanto, representa aquilo que efetivamente se encontra protegido. ${ }^{34}$

Assim, lançadas tais premissas, o que importa é enfatizar que por força da proibição de retrocesso (mas não necessariamente e muito menos exclusivamente em razão desta), o mínimo existencial opera como limite material a vincular negativa (mas também positivamente) o poder público, sem prejuízo de uma eficácia na esfera das relações entre particulares que aqui não está posta em causa. Nessa perspectiva, colaciona-se a emblemática decisão do Tribunal Constitucional de Portugal (Acórdão n. 509/2002), que versa sobre a inconstitucionalidade (por violação do princípio da proibição de retrocesso) do Decreto da Assembléia da República que, ao substituir o antigo rendimento mínimo garantido por um novo rendimento social de inserção, excluiu da fruição do benefício (ainda que mediante a ressalva dos direitos adquiridos) pessoas com idade entre 18 e 25 anos. Em termos gerais e para o que importa neste momento, a decisão, ainda que não unânime, entendeu que a legislação revogada, atinente ao rendimento mínimo garantido, concretizou o direito à segurança social dos cidadãos mais carentes (incluindo os jovens entre 18 e 25 anos), de tal sorte que a nova legis-

${ }_{33}$ Conforme Sarlet (2009, p. 192-93).

${ }^{34}$ Nesse sentido, ver também Queiroz (2006, p. 81 e ss., p. 101 e ss.). 
lação, ao excluir do novo rendimento social de inserção as pessoas nessa faixa etária, sem a previsão e/ou manutenção de algum tipo de proteção social similar, estaria a retroceder no grau de realização já alcançado do direito à segurança social a ponto de violar o conteúdo mínimo desse direito já que atingido o conteúdo nuclear do direito a um mínimo de existência condigna, não existindo outros instrumentos jurídicos que o possam assegurar com um mínimo de eficácia. Destaca-se, ainda, que o Tribunal Constitucional português reiterou pronunciamentos anteriores, reconhecendo que, no âmbito da concretização dos direitos sociais, o legislador dispõe de ampla liberdade de conformação, podendo decidir a respeito dos instrumentos e sobre o montante dos benefícios sociais a serem prestados, sob o pressuposto de que, em qualquer caso, a escolha legislativa assegure, com um mínimo de eficácia jurídica, a garantia do direito a um mínimo de existência condigna para todos os casos. ${ }^{35}$

No âmbito do direito comparado, em termos de aplicação da noção de proibição de retrocesso em matéria de direitos sociais, verifica-se que embora a proibição de retrocesso não opere como barreira intransponível contra a redução dos níveis de prestação (basta ver o que se passa na Europa em matéria de cortes nos vencimentos de servidores públicos em decorrência da crise, como ocorreu na Grécia, Espanha e Portugal), é possível encontrar precedentes dignos de nota, que, embora nem sempre façam referência expressa ao termo proibição de retrocesso ou de regressividade, dizem respeito ao controle de medidas restritivas de direitos sociais. Além dos casos já citados julgados pelo Tribunal Constitucional de Portugal (rendimento social de inserção) e do Tribunal Constitucional Federal da Alemanha (legislação Hartz IV), podem ser citados julgados do Tribunal Constitucional da Colômbia ${ }^{36}$, do Superior Tribunal de Justiça do Brasili ${ }^{37}$ e, mais recentemente, outro importante julgado do Tribunal Constitucional Federal da Alemanha, decidido em 18 de julho de 2012, ocasião na qual o Tribunal considerou inconstitucional o valor da prestação pecuniária alcançada, por força de lei específica, aos requerentes de asilo na Alemanha, sob o argumento de que a prestação não assegura o chamado mínimo existencial.

Ainda que não se possa falar de uma proibição absoluta de retrocesso (ou regressividade) e mesmo que a proibição de retrocesso não constitua nem a única ou mesmo principal forma (consideradas as alternativas disponíveis nas diversas ordens jurídicas) de assegurar os níveis vigentes de proteção social, ou, pelo menos, que tais níveis não sejam reduzidos para aquém do mínimo existencial, o fato é que, precisamente em tempos de crise, cuida-se de importante instrumento político-jurídico, apto a ser assegurado inclusive por meio dos órgãos jurisdicionais nacionais e supranacionais.

\footnotetext{
35 Para quem deseja aprofundar a análise, vale a pena conferir na íntegra a fundamentação do já citado Acórdão n. 509/2002, Processo n. 768/2002, apreciado pelo Tribunal Constitucional de Portugal em 19 de dezembro de 2002.

${ }^{36}$ Conforme, por todos, Uprimny e Guarnizo (2008, p. 37 e ss.), com referência a uma série de julgados do Tribunal Constitucional.

37 Conforme, embora em matéria ambiental, o julgamento do REsp 769753/SC, Rel. Ministro Herman Benjamin, publicado no DJU em 10.06.11.
} 


\section{Considerações finais: alguns desafios e perspectivas}

A diversidade dos modelos de reconhecimento e proteção dos direitos sociais, seja no plano constitucional, seja em nível legislativo ordinário, bem como no que diz respeito às peculiaridades do sistema internacional (e dos sistemas regionais) de direitos humanos e no maior ou menor grau de cumprimento dos seus parâmetros pelos Estados da comunidade internacional, dificilmente permite que se possa partir de uma teoria de base e mesmo de padrões supranacionais indistintos. Se isso já é correto quando se está a falar dos níveis de proteção jurídica, tanto mais a diversidade é determinante quanto estiverem em causa os pressupostos fáticos (econômicos) de fruição dos direitos sociais na condição de direitos a prestações.

$\mathrm{O}$ quanto os órgãos estatais se encontram vinculados pelas obrigações de respeitar, proteger e implementar os direitos a prestações, não encontra resposta uniforme, mas é perceptível que a tendência é de considerar que pelo menos os direitos a prestações vinculados ao mínimo existencial são de efetivação prioritária, de tal sorte que sua violação (seja por ação, seja por omissão, ainda que parcial) ofende não apenas grande parte das constituições, mas entra em rota de colisão com obrigações oriundas do sistema internacional de direitos humanos.

Embora se saiba, por outro lado, que a simples previsão de direitos sociais nos textos constitucionais, mas também nas leis, não é suficiente, por si só, para que se possa ter assegurada a sua efetiva fruição, bem como se tenha presente que o fenômeno da escassez não pode ser pura e simplesmente desconsiderado pelo Direito, o fato é que o direito - inclusive o princípio da proibição de retrocesso social pode ser um fato poderoso para prevenir ou reduzir o impacto da crise, notadamente quando se cuida de assegurar níveis mínimos de igualdade de oportunidades e impor ao Estado obrigações de controle do desperdício, transparência, informação, entre outras. Além disso, é perceptível que a proteção jurídico-constitucional dos direitos sociais, inclusive e em especial na sua condição de direitos a prestações, tem sido um fato relevante tanto como pauta permanente de reivindicações na esfera das políticas públicas quanto como poderoso instrumento para, na ausência ou insuficiência daquelas, ou mesmo pela falta de cumprimento das próprias políticas públicas, propiciar o designado "empoderamento" do cidadão individual e coletivamente considerado para uma ação concreta, ainda que nem sempre idealmente efetiva e, muitas vezes, mais simbólica. Isso, como atende a evolução recente, projeta-se nas relações entre os próprios Estados na esfera supranacional. Nessa perspectiva, o fato de os direitos sociais serem considerados autênticos direitos humanos e fundamentais e, como tais, levados a sério também na sua condição de direitos subjetivos, tem também servido para imprimir à noção de cidadania um novo contorno e conteúdo, potencialmente mais inclusivo e solidário, o que por si só já justificaria todo o esforço em prol dos direitos sociais e nos serve de alento para seguirmos aderindo ao bom combate às objeções manifestamente infundadas que lhes seguem sendo direciona- 
das. Se com os direitos sociais na condição de direitos humanos e fundamentais não se poderá pretender uma soberania absoluta do Direito em relação aos fatos - notadamente em relação à crise -, também é certo que a força normativa (Hesse) dos direitos sociais não os torna completamente reféns da crise; pelo contrário, direitos sociais podem e devem seguir sendo um projeto normativo e vinculante, apesar da crise e como permanente chamado em prol da inclusão e igualdade.

Com efeito, o reconhecimento de que os direitos sociais constituem direitos exigíveis não transforma o Poder Judiciário no agente privilegiado do processo, pois não poderá substituir uma ampla e coerente política dos direitos fundamentais (e não apenas dos direitos sociais) a qual, por mais que seja correta e deva ser endossada, não pode, por seu turno, conduzir ao afastamento dos direitos sociais do crivo dos Tribunais. O que há de ser discutido e melhor equacionado é a forma pela qual há de atuar o Poder Judiciário, visto que este - bem como seus órgãos e agentes também se acha vinculado diretamente pelos deveres de proteção dos direitos fundamentais. Da mesma forma, como foi objeto de várias contribuições citadas neste trabalho, há que apostar mais no estudo do papel do Poder Legislativo e do Poder Executivo, assim como nos mecanismos de aperfeiçoamento do controle social em relação às políticas públicas.

Assim, há como afirmar que um dos principais desafios com os quais nos deparamos atualmente é o de resgatar as boas (pois nem todas talvez o sejam!) promessas da modernidade, entre as quais assume papel de destaque a institucionalização e a permanente "atualidade dos direitos sociais, ${ }^{38}$ " contribuindo para que também as instituições do Estado Democrático de Direito consagrado pela $\mathrm{CF}$ possam, antes tarde do que nunca, tornar efetivas tais promessas, especialmente naquilo que estas dizem respeito à implantação de níveis suficientes de justiça social, em outras palavras, à garantia de uma existência digna (uma vida com qualidade) para todos.

\section{Referências}

ABRAMOVICH, Victor; COURTIS, Christian. Los Derechos Sociales como Derechos Exigibles. 2. ed. Madrid: Editorial Trotta, 2004.

ANDRADE, José Carlos Vieira de. Os Direitos Fundamentais na Constituição Portuguesa de 1976. Coimbra: Livraria Almedina, 1987.

BARCELLOS, Ana Paula de. Constitucionalização das políticas públicas em matéria de direitos fundamentais: o controle político-social e o controle jurídico no espaço democrático. Revista de Direito do Estado, n. 3, 2006.

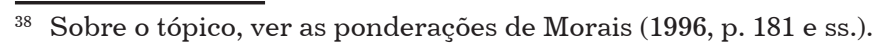


BINENBOJM, Gustavo; CYRINO, André Rodrigues. O direito à moradia e a penhorabilidade do bem único do fiador em contratos de locação. Limites à revisão judicial de diagnósticos e prognósticos legislativos. In: SOUZA NETO, Cláudio Pereira; SARMENTO, Daniel (Coord.). Direitos Sociais. Fundamentos, Judicialização e Direitos Sociais em Espécie. Rio de Janeiro: Lumen Juris, 2008.

BRUNNER, Georg. Die Problematik der sozialen Grundrechte. In: Recht und Staat, Nr. 404-405. Tübingen: J. C. B. Mohr (Paul Siebeck), 1971.

CANOTILHO, José Joaquim Gomes. Constituição Dirigente e Vinculação do Legislador. Coimbra: Ed. Coimbra, 1982.

CANOTILHO, José Joaquim Gomes. Direito Constitucional e Teoria da Constituição. 3. ed. Coimbra: Almedina, 1999.

CANOTILHO, José Joaquim Gomes; MOREIRA, Vital. Fundamentos da Constituição. Coimbra: Ed. Coimbra, 1991.

COMPARATO, Fábio Konder. O Ministério Público na defesa dos direitos econômicos, culturais e sociais. In: CUNHA, Sérgio Sérvulo da; GRAU, Eros Roberto (Org.). Estudos de direito constitucional em homenagem a José Afonso da Silva. São Paulo: Malheiros, 2003.

CONTO, Mario de. Princípio da proibição de retrocesso social. Porto Alegre: Livraria do Advogado, 2008.

COURTIS, Christian (Ed.). Ni un paso atrás. La prohibición de regresividad en material de derechos sociales. Buenos Aires: Editores del Puerto, 2006.

COURTIS, Christian; SANTAMARÍA, Ramiro Ávila (Ed.). La protección judicial de los derechos sociales. Ministerio de Justicia y Derechos Humanos. Quito, 2009.

DERBLI, Felipe. O princípio da proibição de retrocesso social na Constituição de 1988. Rio de Janeiro: Renovar, 2007.

FARIA, José Eduardo. Democracia e Governabilidade: os Direitos Humanos à Luz da Globalização Econômica. In: FARIA, José Eduardo (Org.). Direito e Globalização Econômica: Implicações e Perspectivas. São Paulo: Malheiros, 1996.

FILETI, Narbal Antônio Mendonça. A fundamentalidade dos direitos sociais e o princípio da proibição de retrocesso social. São José: Conceito Editorial, 2009.

FREITAS, Juarez. A Interpretação Sistemática do Direito. 3. ed. São Paulo: Malheiros, 2002. 
GRAU, Eros Roberto. Realismo e Utopia Constitucional. In: ROCHA, Fernando Luiz Ximenes; MORAES, Filomeno (Coord.). Direito Constitucional Contemporâneo. Estudos em Homenagem ao Professor Paulo Bonavides. Belo Horizonte: Del Rey, 2005.

HÄBERLE, Peter. Grundrechte im Leistungsstaat. Veröffentlichungen der Vereinigung der deutschen Staatsrechtslehrer, n. 30, 1972.

HOLMES, Stephen; SUNSTEIN, Cass. The Cost of Rights. Why Liberty Depends on Taxes. New York, London: W. W. Norton \& Company, 1999.

IMIGRANTES protestam contra exclusão de ilegais da saúde na Espanha. Folha de São Paulo, 01 set. 2012. Disponível em: <http://folha.com/no1146983>. Acesso em: 14 set. 2012.

KING, Jeff. Judging Social Rights. Cambridge: Cambridge University Press, 2012.

KRELL, Andreas. Direitos Sociais e Controle Judicial no Brasil e na Alemanha: os (des) caminhos de um direito constitucional "comparado". Porto Alegre: Sergio Fabris, 2002.

LEAL, Rogério Gesta. Estado, Administração Pública e Sociedade: Novos Paradigmas. Porto Alegre: Livraria do Advogado, 2006.

LEAL, Rogério Gesta. O Controle Jurisdicional de Políticas Públicas no Brasil: possibilidades materiais. In: SARLET, Ingo Wolfgang (Org.). Jurisdição e Direitos Fundamentais. Porto Alegre: Livraria do Advogado, 2005.

LIEBENBERG, Sandra. Socio-Economic Rights. Adjudication under a transformative constitution. Cape Town: Juta \& Co Ltd., 2010.

LOPES, José Reinaldo Lima. Direitos Sociais. Teoria e Prática. São Paulo: Método, 2006.

LOUREIRO, João Carlos. Adeus ao Estado Social? A Segurança Social entre o Crocodilo da Economia e a Medusa da Ideologia dos "Direitos Adquiridos". Coimbra: Wolters Kluwer, 2010.

MARTENS, Wolfgang. Grundrechte im Leistungsstaat. Veröffentlichungen der Vereinigung der deutschen Staatsrechtslehre, n. 30, 1972.

MIOZZO, Pablo Castro. A dupla face do princípio da proibição do retrocesso social e os direitos fundamentais no Brasil. Porto Alegre: Verbo Jurídico, 2010.

MIRANDA, Jorge. Manual de Direito Constitucional. 2. ed. Coimbra: Ed. Coimbra, 1993. 
MORAIS, José Luis Bolzan de. Do Direito Social aos Interesses Transindividuais. Porto Alegre: Livraria do Advogado, 1996.

MURSWIEK, Dietrich. Grundrechte als Teilhaberechte, soziale Grundrechte. In: KIRCHHOF Josef Isensee Paul (Org.). Handbuch des Staatsrechts der Bundesrepublik Deutschland. München: C. F. Müller, 2000.

NEVES, Marcelo. Transconstitucionalismo. (Tese apresentada ao concurso de provas e títulos para provimento de cargo de Professor Titular junto ao Departamento de Direito do Estado da Universidade de São Paulo). São Paulo, 2009.

NOVAIS, Jorge Reis. Direitos fundamentais: trunfos contra a maioria. Coimbra: Ed. Coimbra, 2006.

NOVAIS, Jorge Reis. Direitos sociais: teoria jurídica dos direitos sociais enquanto direitos fundamentais. Coimbra: Ed. Coimbra, 2010.

NOVAIS, Jorge Reis. Os Princípios Constitucionais Estruturantes da República Portuguesa. Coimbra: Ed. Coimbra, 2004.

PINHO E NETO, Luísa C. O princípio de proibição de retrocesso social. Porto Alegre: Livraria do Advogado, 2010.

PINTO, Élida Graziane. Financiamento dos direitos à saúde e à educação. Uma perspectiva constitucional. Belo Horizonte: Fórum, 2014.

PIRARELLO, Gerardo. Los derechos sociales y sus garantias. Elementos para uma reconstrucción. Madrid: Editorial Trotta, 2007.

QUEIROZ, Cristina M. M. Direitos fundamentais sociais. Funções, Âmbito, Conteúdo, Questões Interpretativas e Problemas de Justiciabilidade. Coimbra: Ed. Coimbra, 2006.

QUEIROZ, Cristina M. M. O princípio da não reversibilidade dos direitos fundamentais sociais. Coimbra: Ed. Coimbra, 2006.

SANTOS, Boaventura Sousa. Reinventar a Democracia. Lisboa: Gradiva, 1998.

SARLET, Ingo Wolfgang. A assim designada proibição de retrocesso social e a construção de um direito constitucional comum latino-americano. Revista Brasileira de Estudos Constitucional, n. 11, jul./set. 2009a.

SARLET, Ingo Wolfgang. A Eficácia dos Direitos Fundamentais. Uma Teoria dos Direitos Fundamentais na Perspectiva Constitucional. 10. ed. Porto Alegre: Livraria do Advogado, 2009b. 
SARLET, Ingo Wolfgang. Os Direitos Fundamentais Sociais na Constituição de 1988. In: SARLET, Ingo Wolfgang (Org.). Direito Público em Tempos de Crise: estudos em homenagem a Ruy Ruben Ruschel. Porto Alegre: Livraria do Advogado, 1999 .

SARLET, Ingo Wolfgang; TIMM, Luciano B. (Org.). Direitos Fundamentais, Orçamento e Reserva do Possível. 2. ed. Porto Alegre: Livraria do Advogado, 2010.

SILVA, Virgílio Afonso da. O Judiciário e as Políticas Públicas: entre transformação social e obstáculo à realização dos direitos sociais. In: SOUZA NETO, Cláudio P.; SARMENTO, Daniel (Coord). Direitos Sociais. Rio de Janeiro: Lumen Juris, 2008.

STARCK, Christian. Staatliche Organisation und Staatliche Finanzierung als Hilfen zu Grundrechtsverwirklichungen? In: MOHR, J. C. B. Bundesverfassungsgericht und Grundgesetz aus Anla des 25 jährigen Bestehens des Bundesverfassungsgerichts (Paul Siebeck). Tübingen, 1976.

STRAPAZZON, Carlos Luiz. Âmbito de Proteção de Direitos Fundamentais de Seguridade Social: expectativas imperativas de concretização. In: SARLET, Ingo Wolfgang et al. (Org.). Constituição e Direitos Fundamentais: estudos em torno dos fundamentos constitucionais do direito público e do direito privado. Porto Alegre: Livraria do Advogado, 2012.

SUNSTEIN, Cass R. The Second Bill of Rights. New York: Basic Books, 2004.

TUSHNET, Mark; COURTS, Weak. Strong Rights. Princeton and Oxford: Princeton University Press, 2008.

UPRIMNY, Rodrigo; GUARNIZO, Diana. Es posible uma dogmática adecuada sobre la prohibición de regresividad? Un enfoque desde la jurisprudência constitucional. Direitos Fundamentais e Justiça, n. 3, 2008.

WIEGAND, Dietrich. Sozialstaatsklausel und soziale Teilhaberechte. In: Deutsches Verwaltungsblatt, 1974.

YAMIN, Alícia Ely; GLOPPEN, Siri (Ed.). Litigating Health Rights. Can Courts Bring More Justice to Health. Cambridge: Harvard University Press, 2011.

ZACHER, Hans-Friedrich. Das soziale Staatsziel. In: ISENSEE, Josef; KIRCHHOF, Paul (Coord.). Handbuch des Staatsrechts der Bundesrepublik Deutschland. Heidelberg: C. F. Müller, 1987.

Data da submissão: 30 de março de 2015 Avaliado em: 13 de abril de 2015 (Avaliador A) Avaliado em : 26 de abril de 2015 (Avaliador B) Avaliado em : 27 de abril de 2015 (Avaliador C)

Aceito em: 15 de junho de 2015 